I. Crônicas

1. Crônicas da atualidade do Direito Internacional ......................................................16

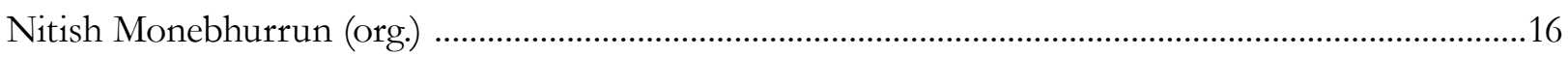

2.Decisões da Corte Internacional de Justiça e do Tribunal Internacional Sobre o Direito do Mar

Nitish Monebhurrun

José Eduardo Siqueira

3. Crônicas do direito internacional dos inVestimentos

Nitish Monebhurrun

\section{Os Vinte Anos dA OMC}

EXPORT CONTROLS AS INDUSTRIAL POLICY ON NATURAL RESOURCES: REGULATORY LIMITATIONS ON CHINA - RAW MATERIALS AND CHINA - RARE EARTHS CASES.

Gustavo Ferreira Ribeiro

O problema da espionagem econômica internacional: Seria a Organização Mundial do CoMÉRCIO O FORO ADEQUADO PARA SUA APRECIAÇÃO?

Humberto A.Vasconcelos Lima

Naiana Magrini Rodrigues Cunha

International Standards for Intellectual Property Rights Protection: a reflection on CLIMATE-FRIENDLY TECHNOLOGY TRANSFER.

Guihong Zhang

Jiani Jiang

Can Wang

Os vinte anos da OMC, suas conquistas e desafios: uma análise do Brasil e o Sistema de SoLUÇõES DE CONTROvÉRsias

Etiene M. Bosco Breviglieri

Luciano Meneguetti Pereira

A relação entre os tratados multilaterais ambientais e os acordos da OMC: é possível CONCILIAR O CONFLITO?

Fabio Costa Morosini,

Luisa Zuardi Niencheski 
Um desafio na Organização Mundial do Comércio: viabilidade de um aCordo plurilateral SOBRE ENERGIA.

Matheus Linck Bassani

ContrataÇões PÚblicas No ÂMBITO da OMC: A POLÍTICA LEGISLATIVA BRASILEIRA À LUZ DO DIREITO AO DESENVOLVIMENTO

André Jansen do Nascimento

Governança global e a Organização Mundial do Comércio: desafios impostos Pelo novo MANDATO DE DESENVOLVIMENTO .218

Letícia de Souza Daibert

Ana Luísa Soares Peres

Vinte Anos de Crise para a África? Poder, Assimetrias e a Abordagem Liberal da OMC.....239 Igor Abdalla Medina de Souza

Os MECANISMOS DE INDUÇÃo AO CUMPRIMENTO NO ÂMBITO DA OMC. .258

Fernando Lopes Ferraz Elias

A promoção de accountability na Organização Mundial do Comércio: uma análise horiZONTAL E VERTICAL .280

Celso Henrique Cadete de Figueiredo

LA OMC Y EL PROCESO DE GLOBALIZACION DE LA REGULACIÓN ALIMENTARIA .307

Maria Eugenia Marichal

O ACORDO GATS E SUA APLICAÇÃo AOS SERVIÇOS DO COMÉRCIO ELETRÔNICO

Gleisse Ribeiro Alves

A OMC E o Regionalismo do SÉCUlo XXI: ESTRATÉgia de IMPOSIÇÃo de MODELOS NORMATIVOs? .. 337 Camilla Capucio

A organização mundial do comércio e a China: direito de Propriedade e propriedade inteLECTUAL NO PAÍS

Dos contenciosos NA OMC COM ENFOQUE EM RESTRIÇõES Às EXPORTAÇÕEs DA CHINA .363 Marco Antônio Alcântara Nascimento 
O redimensionamento da OMC no trato dos Acordos Comerciais Regionais.

Alice Rocha da Silva

\section{Outros Temas}

Derechos Humanos en la REALIDAD ACTUAL: LA GLOBALIZACión Y El MUlTiCUlturalismo

David Falcão

IMUNIDADE DE JURISDIÇÃo dO EsTADO E REPARAÇÃo CIVIL PELA PRÁTICA DE TORTURA: O CASO ZAHRA

KAZEMI v. REPÚBLICA ISLÂMICA DO IRÃ

Patrícia Maria Lara Abreu

Rodrigo Otávio Bastos Silva Raposo

INTERREgIONAL ORgANIZATIONS (IROS) IN EUROPE: NEW SUBJECTS OF CONTEMPORARY INTERNATIONAL LAW?

Davorin Lapas

A CONEXÃo ENTRE OS DiREITOS HUMANOS E A CORRUPÇÃo

Gabriela Alves Mendes Vieira

Marcelo Dias Varella

GRUPO DE SOCIEDADES: INSTRUMENTO JURÍDICO DE ORGANIZAÇÃO DA EMPRESA PLURISSOCIETÁRIA

Daniel Amin Ferraz 


\title{
Da nacionalidade como direito humano: da necessária ampliação das hipóteses de aplicação do critério do jus sanguinis nos casos de adoção internacional*
}

\author{
Nationality as a human right: the need to expand \\ the application of jus sanguinis hypotheses \\ criterion for cases of intercountry adoption
}

Hitala Mayara Pereira de Vasconcelos

\section{Resumo}

A Convenção da Haia de 1993, ao regular a adoção internacional, manteve um silêncio normativo sobre os seus efeitos no que se refere à nacionalidade da criança adotada. Com isso, a questão tornou-se objeto de interpretação judicial, a demandar considerações sobre qual percepção deve ser adotada no que se refere à noção de nacionalidade, compreendendo-a não como mero fruto do reconhecimento estatal, mas direito humano, elevando o nacional à condição de sujeito de direitos. No Brasil, apesar da previsão do artigo 227, $\$ 6^{\circ}$, da Constituição, que equipara os filhos naturais e adotivos sem quaisquer ressalvas, vem prevalecendo uma interpretação restritiva sobre o tema, que se contrapõe à posição de vanguarda do país no que concerne à redução dos casos de apatridia. Este estudo visa, portanto, examinar os fundamentos da posição restritiva adotada pelo Brasil, contrapondo-a ao entendimento das Cortes regionais de proteção aos Direitos Humanos sobre a matéria. Com isso, poderemos concluir pela necessidade de ampliação das hipóteses de aplicação do critério do jus sanguinis para os casos de adoção internacional, incluindo os filhos adotivos dentre os brasileiros natos nas situações do artigo 12, inciso I, alíneas "b" e "c" da Constituição brasileira.

Palavras-chave: Nacionalidade. Apatridia. Adoção Internacional. Interpretação evolutiva.

\section{Abstract}

The Hague Convention of 1993, to regulate the adoption, kept silence on its legal effects about the adopted children nationality. Because of that, the issue has become the subject of judicial interpretation what demands considerations about which perception should be taken regarding the notion of nationality, no longer understood as a State recognition but as a Human Right, promoting the national to a position of subject of rights. In Brazil, despite article 227, $\$ 6^{\circ}$, of its Constitution, which equalizes natural and adoptive children with no exceptions, a limited position about this theme prevails, what contrasts with the forefront of the country on reduction of statelessness. The aim of this study is to analyse the bases of the limited position adopted by Brazil in contrast to the Regional Courts position for the protection of Human Rights on the matter. Thus, we can conclude by the need to expand the application of jus sanguinis hypotheses criterion for cases of intercountry adoption, including adoptive children among native Brazilians under circunstances of article 12, item I, points "b" and "c" of Brazilian Constitution. Keywords: Nationality. Statelessness. Intercountry Adoption. Evolutionary Interpretation.

* Recebido em: 25.09 .2014

Aceito em: 12.11.2014

** Advogada da União. Graduada em Direito pela Universidade Federal de Pernambuco. Mestranda em Direito das Relações Internacionais pelo Centro Universitário de Brasília - Uniceub. E-mail: hitalampv@ hotmail.com. 


\section{Introdução1}

Em meados de agosto de 2014, o Ministério da Justiça anunciou a conclusão dos trabalhos de elaboração do anteprojeto de lei destinado a revogar o Estatuto do Estrangeiro (Lei $\mathrm{n}^{\circ}$ 6.815, de 19 de agosto de 1980), anunciando-o como o 'Anteprojeto de lei de migrações e promoção dos direitos dos migrantes no Brasil'.

Seu texto foi resultado do trabalho de uma comissão de juristas que incluía professores universitários, membros do Ministério Público, cientistas políticos e especialistas em direitos humanos e, segundo expôs o Ministro da Justiça, uma de suas principais características consistiu no abandono do Estatuto do Estrangeiro - fruto do governo ditatorial - em virtude da necessidade de compatibilizar o regime jurídico do migrante com a Constituição brasileira e com os tratados vigentes sobre direitos humanos, inclusive quanto à nomenclatura adotada, substituindose a expressão — tida por pejorativa — 'estrangeiro' por 'migrante'.

Dias antes, o Ministério anunciava também a conclusão de um outro anteprojeto de lei, elaborado em conjunto com o Alto Comissariado das Nações Unidas para Refugiados (ACNUR) no Brasil, voltado à criação de um processo de determinação da condição de apátrida no país, com o estabelecimento de direitos e obrigações para essas pessoas².

Por facilitar a aquisição da nacionalidade brasileira pelo apátrida, o anteprojeto foi elogiado pelo Oficial Regional de Proteção do Alto Comissariado da ONU para Refugiados para o tema da apatridia nas Américas, o qual, além de apontar o Brasil como um exemplo para os demais países da América Latina, ainda destacou a importância da atuação administrativa do país durante o período de vigência da emenda constitucional de

1 Essas informações foram disponibilizadas no sítio eletrônico do Ministério da Justiça, e a notícia foi divulgada no dia 29 de agosto de 2014, data da entrega do anteprojeto de lei à Presidência da República. BRASIL. Ministério da Justiça. Entenda o Anteprojeto de Lei de Migraçoes. Disponível em: <http://www.justica.gov.br/noticias/ proposta-de-nova-lei-de-migracoes-devera-substituir-estatutocriado-durante-a-ditadura/entenda_novo_estatutoestrangeiro2. pdf>. Acesso em: 30 ago. 2014.

2 A notícia foi divulgada no dia 14 de agosto de 2014 e disponibilizada no sítio eletrônico do Ministério da Justiça. BRASIL. Ministério da Justiça. Governo do Brasil anuncia projeto de lei para proteger pessoas sem pátria. Disponível em: <http://www.justica.gov.br/ noticias/governo-do-brasil-anuncia-projeto-de-lei-para-protegerpessoas-sem-patria>. Acesso em: 30 ago. 2014. revisão n ${ }^{\circ}$, de 1994, que, alterando a alínea "c" do inciso I do artigo 12 da Constituição de 1988, reduziu as hipóteses de reconhecimento da nacionalidade brasileira para os filhos de brasileiros nascidos no exterior, demandando outras medidas que resolvessem a situação gerada pelo aumento no número de crianças apátridas $^{34}$.

Essas medidas sinalizam a adoção, pelo Brasil, de uma posição mais atual sobre o tema da nacionalidade, compreendida não mais como mero reflexo da soberania estatal, dependente exclusivamente do reconhecimento do Estado, e sim como um direito humano, posição que demanda também uma atuação proativa no combate à apatridia pelo Estado, por não se poder negar a importância da nacionalidade como pressuposto para a proteção dos demais direitos humanos.

Mas, apesar de relevantes, convém observar se tais medidas normativas refletem uma posição uníssona do Estado brasileiro - quanto à atuação dos seus três Poderes —, tomando-se por parâmetro nesta observação o tema da nacionalidade em matéria de adoção internacional, especificamente nas hipóteses em que a Constituição adota o critério do jus sanguinis para a atribuição da nacionalidade brasileira.

O artigo 12, inciso I, alíneas "b" e "c", da Constituição, apenas atribui a condição de brasileiro nato ao nascido no estrangeiro, de pai brasileiro ou mãe brasileira, desde que qualquer deles esteja a serviço da República Federativa do Brasil, ou desde que a criança seja registrada em repartição brasileira competente ou venha a residir no país e opte a qualquer tempo, após a maioridade, pela nacionalidade brasileira, sendo silente em relação aos casos de adoção no estrangeiro ${ }^{5}$ por

3 A íntegra da notícia pode ser consultada no sítio eletrônico do ACNUR no Brasil. ACNUR. Governo do Brasil anuncia projeto de lei para protegerpessoas sem pátria. Disponível em: < http://www.acnur.org/t3/ portugues/noticias/noticia/governo-do-brasil-anuncia-projeto-delei-para-proteger-pessoas-sem-patria/>. Acesso em: 30 ago. 2014.

4 Vale destacar que a alteração realizada pela emenda constitucional de revisão n ${ }^{\circ}$ 3, de 1994, na alínea "c" do art. 12, inciso I, da Constituição de 1988 não mais opera efeitos, já que foi dada nova redação ao dispositivo com a emenda constitucional $n^{\circ} 54$, de 2007. Apesar disso, sua importância é frequentemente ressaltada por ter sido sua promulgação objeto para diversos problemas envolvendo crianças, filhas de pai(s) brasileiro(s), que, por residirem em locais que adotavam o jus sanguinis, se tornariam apátridas, problemas estes que, à época, foram amenizados através de medida provisória que autorizou a expedição de passaportes provisórios pelo país, somente vindo a ser sanados com a nova redação do artigo constitucional.

5 Vale frisar que o que define uma adoção como internacional não é a nacionalidade dos adotantes ou do adotado, e sim a mudança do local de residência habitual que ela impõe à criança. Esse é o 
pai ou mãe brasileiro nas mesmas hipóteses, apesar da previsão do artigo $227, \S 6^{\circ}$, que prescreve a igualdade de direitos entre os filhos naturais e os havidos por adoção.

Nesse cenário, passível de propiciar a ocorrência da apatria por choque entre critérios de atribuição de nacionalidade, é que se mostra pertinente uma análise sobre quais medidas o direito brasileiro prevê para assegurar o direito humano à nacionalidade à criança adotada no exterior, sendo este tema o objeto do nosso estudo.

Para tanto, iniciaremos observando a evolução do próprio conceito de nacionalidade e sua relação com a soberania do Estado, examinando seus efeitos e a importância de seu reconhecimento. Desse modo, faremos um exame sobre os instrumentos codificados em vigor, analisando sua teleologia e qual interpretação lhes vêm sendo dada pelas Cortes regionais de proteção de direitos humanos.

Mesma lógica será adotada em seguida quanto ao tema da adoção internacional, momento em que examinaremos sua evolução histórica e de que modo as Cortes de direitos humanos vêm compreendendo os efeitos do princípio da proteção ao superior interesse da criança, seu fundamento principal.

Concluído esse exame, poderemos indagar sobre o grau de aplicabilidade do artigo 227, \$6 $6^{\circ}$, da Constituição brasileira, no que se refere especificamente a seus efeitos em relação à nacionalidade, verificando se as mudanças normativas propostas e se as decisões judiciais já proferidas sobre o tema sinalizam ou não a ocorrência de um avanço no direito pátrio sobre a matéria.

Com isso, será possível observar que o Brasil ainda precisa avançar na temática, mas agora não necessariamente na edição de novas normas, e sim na interpretação das já existentes, afastando a concepção restritiva de nacionalidade, bem como o caráter eminentemente patrimonial da adoção, para ampliar a equiparação de direitos entre filhos naturais e adotivos de modo a englobar também o direito de reconhecimento da condição de brasileiro nato aos filhos adotivos, não obstante o silêncio constitucional sobre a questão.

conceito que se infere do artigo 2 da Convenção da Haia relativa à proteção das crianças e à cooperação em matéria de adoção internacional, de 1993. BRASIL. Decreto n. 3.087, de 21 de junho de 1999. Disponível em: <http://www.planalto.gov.br/ccivil_03/ decreto/d3087.htm>. Acesso em: 30 ago. 2014.

\section{Da evolução do conceito de nacionalidade: do mero reflexo da soberania estatal para a noção de direito humano}

Consistindo no "vínculo político entre o Estado soberano e o indivíduo, que faz deste um membro da comunidade constitutiva da dimensão pessoal do Estado", a nacionalidade, embora constitua tema de inegável importância para o direito internacional, ainda é disciplinada eminentemente pelo direito interno de cada Estado, pois a este compete definir aqueles que serão reconhecidos como seus nacionais.

Mas, embora seja algo histórico a necessidade do Estado de estabelecer distinção entre seus nacionais e os estrangeiros, constatou-se que essa distinção não poderia ser algo desarrazoado, tampouco justificar o exercício da violência ou da ameaça com base na soberania ${ }^{7}$. Percebeu-se que a lei internacional não mais podia admitir como absoluta a soberania em matéria de emigração, naturalização, nacionalidade e expulsão ${ }^{8}$.

Essa percepção demandou ao direito internacional estabelecer interpretações e limites à disciplina jurídica do tema, o que ocorreu principalmente após a segunda guerra mundial, em virtude das tragédias por ela ocasionadas, que resultaram em milhares de pessoas refugiadas, órfãs e, principalmente, violentadas pelas consequências que a falta de uma nacionalidade específica lhes gerou ${ }^{9}$ em virtude da utilização da nacionalidade como um critério de exclusão ${ }^{10}$.

6 REZEK, Francisco. Direito internacional público: curso elementar. 14. ed., rev., aumen. e atual. São Paulo: Saraiva, 2013. p. 218.

7 Essa percepção é apresentada pela Comissão Interamericana de Direitos Humanos CORTE INTERAMERICANA DE DERECHOS HUMANOS. 2005. Sentença de 8 de septiembre, Niñas Yean y Bosico v República Dominicana. Disponível em: <http://webcache. googleusercontent.com/search?q=cache:TDCsDySXg2sJ:www. corteidh.or.cr/docs/casos/articulos/seriec_130_esp. $\mathrm{doc}+\& \mathrm{~cd}=2 \& \mathrm{hl}=$ pt-BR\&ct $=\mathrm{clnk} \& \mathrm{gl}=\mathrm{br}>$. Acesso em: 10 set. 2014.

8 Hannah Arendt vai além, para afirmar que 'somos quase tentados a medir o grau de infecção totalitária de um governo pelo grau em que usa o seu soberano direito de desnacionalização'. ARENDT, Hannah. As origens do totalitarismo. Tradução Roberto Raposo. São Paulo: Companhia das letras, 1989. p. 312.

9 Essa percepção é apresentada também por Hannah Arendt, que destaca que o apátrida, consistindo aparentemente em uma anomalia legal, apenas recebe atenção tardia após a segunda guerra mundial, juntamente com os refugiados, que consistiam em pessoas expulsas de seus países pela revolução social, quando eram desnacionalizados pelos governos vitoriosos. ARENDT, Hannah. As origens do totalitarismo. Tradução Roberto Raposo. São Paulo: Companhia das Letras, 1989. p. 311.

10 LOPES, Cristiane Maria Sbalqueiro. Direito de imigração: o 
A passagem do tempo demonstrou que se estava vivenciando um momento de transformação da soberania, que impunha sua flexibilização tanto no plano interno quanto no externo em virtude da necessidade de integração entre os poderes estatais e de afirmação de uma supremacia dos princípios e dos valores ${ }^{11}$ que determinaram uma reinterpretação dos institutos com a finalidade de adequá-los a essa nova conjuntura marcada pela proteção aos direitos humanos já fortemente violados.

Desse modo, o cenário internacional passou a idealizar princípios que deveriam orientar o exercício da soberania estatal, de forma que, mesmo ainda atribuindo ao Estado liberdade para determinar, por meio de sua legislação interna, quais são os seus nacionais, essa liberdade deveria estar orientada por um mínimo de efetividade, de acordo com "as convenções internacionais, costumes internacionais e princípios de direito geralmente reconhecidos em matéria de nacionalidade ${ }^{12}$ ", sob pena de sua legislação não ser aceita pelos demais Estados ${ }^{13}$.

Nesse aspecto é que se consagrou como princípio geral do direito internacional a regra segundo a qual o Estado não pode arbitrariamente privar o indivíduo de sua nacionalidade, nem do direito de mudar de nacionalidade, previsão expressa do artigo 15 da Declaração Universal dos Direitos do Homem de $1948^{14}$. Desse duplo preceito decorre, ainda, a constatação de que todo indivíduo tem direito a uma nacionalidade ${ }^{15}$.

Estatuto do Estrangeiro em uma perspectiva de Direitos Humanos. Porto Alegre: Núria Fabris, 2009. p. 133.

11 BUSTAMANTE, Thomas da Rosa. Teoria do Precedente judicial: a justificação e a aplicação das regras jurisprudenciais. São Paulo: Noeses, 2012. p. 33.

12 BRASIL. Decreto n. 21.798, de 6 de setembro de 1932. Disponível em: $\quad<$ http://legis.senado.gov.br/legislacao/ListaTextoIntegral. action?id=34326. Acesso em: 4 set. 2014.

13 Rezek destaca que, embora pareça haver uma contradição entre os artigos 1 e 2 da Convenção da Haia sobre conflitos de nacionalidade, essa contradição deve ser sanada pela compreensão de que o artigo 2, ao falar em "legislação do Estado", deve ser compreendido como englobando também todos os compromissos desse Estado no cenário internacional, o que inclui as convenções, costumes e princípios gerais do direito, listados de modo expresso no artigo 1. REZEK, José Francisco. Le Droit International de la Nationalité. Leiden: M. Nijhoff, 1987. (Recueil des Cours de l'Académie de droit international, 198). p. 333-400.

14 ORGANIZAÇÃO DAS NAÇÕES UNIDAS. Declaração Universal dos Direitos do Homem de 1948. Disponível em: <http:// www.ohchr.org/EN/UDHR/Documents/UDHR_Translations/ por.pdf>. Acesso em: 30 ago. 2014.

15 REZEK, Francisco. Direito Internacional Público: curso
Apesar da possível baixa efetividade do preceito ${ }^{16}$, ele já foi reputado suficiente para garantir pronunciamento da Corte Europeia de Direitos Humanos em sua defesa, o que ocorreu no caso Genovese versus Malta, quando a Corte fixou a posição de que, embora caiba ao Estado definir quem são seus nacionais, essa definição não pode se pautar em critérios discriminatórios ou desarrazoados, como ocorre, por exemplo, nos casos em que o Estado não reconhece como nacional o filho havido fora do casamento, ainda que seu genitor seja nacional do Estado de nascimento - situação na qual ao filho concebido na constância do casamento seria atribuída a mesma nacionalidade do pai ${ }^{17}$.

Com o intuito de assegurar efetividade à garantia de nacionalidade a todo e qualquer indivíduo, a Convenção Americana de Direitos Humanos, de 1969, foi além, estipulando o jus soli como critério subsidiário de atribuição de nacionalidade ${ }^{18}$, aplicável sempre que a pessoa não tiver direito a outra nacionalidade, exatamente em virtude da facilidade na sua aplicação, que reduziria substancialmente a incidência dos casos de apatridia ${ }^{19}$.

elementar. 14. ed., rev., aumen. e atual. São Paulo: Saraiva, 2013. p. 220.

Também a Convenção Americana sobre Direitos Humanos, de 1969, é expressa ao prever que 'toda pessoa tem direito a uma nacionalidade' (art. 20). BRASIL. Decreto n. 678, de 6 de novembro de 1992. Disponível em: <http://www.planalto.gov.br/ccivil_03/ decreto/D0678.htm>. Acesso em: 30 ago. 2014.

A Convenção sobre a nacionalidade da mulher, por sua vez, estabelece a impossibilidade de utilização do sexo como fator de discriminação em matéria de nacionalidade (artigo 1). BRASIL. Decreto n. 2.411, de 23 de fevereiro de 1938. Disponível em: <http://www2.camara.leg.br/legin/fed/decret/1930-1939/ decreto-2411-23-fevereiro-1938-345944-publicacaooriginal-1-pe. html>. Acesso em: 30 ago. 2014.

16 Essa é a posição do Professor Marcelo Varella, para quem essas normas possuem baixa efetividade 'porque, na relação entre Estado e indivíduos, prepondera a vontade dos Estados, não havendo como ou a quem recorrer caso um Estado crie uma regra impedindo um indivíduo de ter sua nacionalidade. VARELLA, Marcelo Dias. Direito Internacional Público. 3. ed. São Paulo: Saraiva, 2011. p. 179.

17 EUROPEAN COURT OF HUMAN RIGHTS. Cours Européenne des Dois de L'Homme. 2011. Sentença de 11 de outubro, Genovese v. Malta, Application no. 53124/09. Disponível em: < http://hudoc.echr.coe.int/sites/eng/pages/search.aspx?i=001106785\#\{“itemid”:[“001-106785”]\}>. Acesso em: 30 ago. 2014.

18 BRASIL. Decreto $n^{\circ} 678$, de 6 de novembro de 1992. Disponível em: <http://www.planalto.gov.br/ccivil_03/decreto/D0678.htm>. Acesso em: 30 ago. 2014.

19 A questão é enfatizada por Francisco Rezek, que destaca, ainda, que "esse percuciente princípio não veio à luz, originalmente, em São José da Costa Rica", tendo sido previsto quinze anos antes, pela Comissão do Direito Internacional da ONU em um projeto de convenção "para a supressão da apatria no futuro", que, contudo, 
Previsão semelhante já constava da Convenção para a Redução dos Casos de Apatridia, de 1961, a qual, em seu artigo 1, determinava que 'todo Estado Contratante concederá sua nacionalidade a uma pessoa nascida em seu território e que de outro modo seria apátrida', estipulando, ainda, em outros dispositivos, a possibilidade de atribuição da nacionalidade da mãe (artigo 1.3) ou a do país onde ocorreu o abandono da criança (artigo 2), tudo com vistas a minorar o número de apátridas ${ }^{20}{ }_{-}^{21}$.

Mas, mais do que o vínculo formal, é na existência de laços sociais entre o Estado e o indivíduo que a nacionalidade ganha importância, pois, com isso, abandona-se a ideia do nacional como parte integrante do Estado ${ }^{22}$, reconhecendo-o como 'sujeito de direito de uma relação jurídica como Estado', condição indispensável para garantia de sua dignidade humana ${ }^{23}$.

A nacionalidade, originária de um movimento revolucionário de transformação social,

ganhou dimensão universal relevante na compreensão da sociedade moderna, especialmente por conta de sua correlação com a constituição dos direitos dos cidadãos. ${ }^{24}$

acabou arquivado. REZEK, Francisco. Direito Internacional Público: curso elementar. 14. ed., rev., aumen. e atual. São Paulo: Saraiva, 2013. p. 224.

20 ORGANIZAÇÃO DAS NAÇÕES UNIDAS. Convençãopara a redução dos casos de apatridia. Disponível em: <http://www.acnur.org/ t3/fileadmin/Documentos/portugues/BDL/Convencao_para_a_ Reducao_dos_Casos_de_Apatridia_de_1961.pdf?view=1 >. Acesso em: 30 ago. 2014.

21 A ideia de utilização do vínculo dos pais como mecanismo para ampliar, e não para limitar as hipóteses de atribuição da nacionalidade também foi reconhecida pela Corte Interamericana de Direitos Humanos no caso Las Niñas Yean y Bosico v. República Dominicana CORTE INTERAMERICANA DE DERECHOS HUMANOS. 2005. Sentença de 8 de septiembre, Niñas Yean y Bosico v República Dominicana. Disponível em: <http://webcache.googleusercontent. $\mathrm{com} / \mathrm{search}$ ?q= cache:TDCsDySXg2sJ:www.corteidh.or.cr/ $\mathrm{docs} / \mathrm{casos} / \operatorname{articulos} / \mathrm{seriec} \_130 \_$esp.doc $+\& \mathrm{~cd}=2 \& \mathrm{hl}=\mathrm{pt}-$ $\mathrm{BR} \& \mathrm{ct}=\mathrm{clnk \& gl}=\mathrm{br}>$. Acesso em: 10 set. 2014.

22 E, assim, afasta-se qualquer ideia de que tem o Estado o poder de realizar uma desnacionalização forçada, o que, como destacado por Hannah Arendt, ocasionou o surgimento de diversos apátridas e refugiados no período entre guerras.

23 FONTES, André R. C. Nacionalidade brasileira e adoção internacional. Disponível em: <www.tre-rj.gov.br/eje/gecoi_ arquivos/arq_051202.docx>. Acesso em: 30 ago. 2014.

24 HERANI, Renato Gugliano. Nacionalidade potestativa após a Emenda Constitucional 54/07. Disponível em: <http://www. periodicos.ufgd.edu.br/index.php/videre/article/viewFile/899/ pdf_49. Acesso em: 8 nov. 2012.
Uma vez que o 'povo' se une e se relaciona por esse status comum que os liga entre si e com o Estado.

$\mathrm{E}$ isso ocorre porque não se pode pretender desnacionalizar a proteção aos direitos humanos, observação que justifica a atuação do direito internacional no sentido de impor não só limites, mas a própria adoção de medidas positivas de combate à apatridia pelos Estados $^{25}$.

Essa percepção também foi apontada pela Corte Interamericana de Direitos Humanos no caso Ivcher Bronstein versus Peru, no qual, em remissão ao quanto já decidido no Caso Castillo Petruzzi versus outros, entendeu-se que o direito a uma nacionalidade significa dotar o indivíduo de um mínimo de amparo jurídico, de modo que privá-lo da nacionalidade de forma arbitrária significa privá-lo de seus próprios direitos políticos e dos direitos civis que são sustentados pelo vínculo com o Estado ${ }^{26}$.

No caso Las Niñas Yean y Bosico versus República Dominicana, a Corte Interamericana destacou que a falta de reconhecimento de uma nacionalidade impede o próprio reconhecimento da personalidade jurídica e, com isso, viola flagrantemente a dignidade humana, já que nega ao indivíduo de forma absoluta sua condição de sujeito de direitos ${ }^{27}$.

Tornou-se necessário que, por força de sua natureza de direito humano, a nacionalidade adquirisse o foro de matéria de direito das gentes e, nesse sentido, passível

25 Nesse sentido, veja-se que a Convenção sobre o Estatuto dos Apátridas, aprovada em Nova Iorque em 28 de setembro de 1954, e promulgada pelo Brasil através do Decreto $\mathrm{n}^{\circ} 4.246$, de 22 de maio de 2002, estabelece o dever dos Estados de adotarem as medidas necessárias para facilitar a naturalização dos apátridas que estejam em seu território (artigo 22). BRASIL. Decreto n. 4.246, de 22 de maio de 2002. Disponível em: <http://www.planalto.gov.br/ccivil_03/ decreto/2002/D4246.htm>. Acesso em: 30 ago. 2014.

26 Tradução livre do seguinte trecho: "El derecho a tener una nacionalidad significa dotar al individuo de un mínimo de amparo jurídico en las relaciones internacionales, al estabelecer a través de su nacionalidad su vinculación conun Estado determinado; y El de proteger lo contra la privación de su nacionalidade en forma arbitraria, porque de ese modo se le estaria privando de la totalidad de sus derechos políticos y de aquellos derechos civiles que se sustentan en la nacionalidad del individuo". CORTE INTERAMERICANA DE DERECHOS. 2001. Sentença de 6 de fevereiro, Ivcher Bronstein v. Peru. Disponível em: <http://www.corteidh.or.cr/docs/casos/ articulos/Seriec_74_esp.pdf>. Acesso em: 10 set. 2014.

27 CORTE INTERAMERICANA DE DERECHOS HUMANOS. 2005. Sentença de 8 de septiembre, Niñas Yean $y$ Bosico v República Dominicana. Disponível em: <http://webcache. googleusercontent.com/search?q=cache:TDCsDySXg2sJ:www. corteidh.or.cr/docs/casos/articulos/seriec_130_esp. $\mathrm{doc}+\& \mathrm{~cd}=2 \& \mathrm{hl}=\mathrm{pt}-\mathrm{BR} \& \mathrm{ct}=\mathrm{clnk} \& \mathrm{gl}=\mathrm{br}>$. Acesso em: 10 set. 2014 . 
de ingerência e de decisões por outros entes de direito internacional que não apenas o Estado soberano, tudo isso com o intuito de combater não só a apatridia de jure, a qual considera como apátrida aquele que não é reconhecido, por qualquer Estado, como seu nacional ${ }^{28}$, mas também a apatridia de fato, que acomete aqueles que possuem uma nacionalidade diversa da do Estado onde vivem $^{29}$.

Essa intervenção do direito internacional sobre a matéria passou a ser sentida no plano estatal, e não apenas em relação aos Estados que aderiram aos tratados internacionais voltados à redução dos casos de apatridia, mas por todos, uma vez que os direitos humanos se impõem pela própria lógica do cenário internacional ${ }^{30}$.

No Brasil, essa internacionalização do direito interno foi reconhecida pela Constituição, que, em seu artigo $5^{\circ}, \$ 3^{\circ}$, com a redação dada pela Emenda Constitucional $\mathrm{n}^{\circ} 45$, de 2004, declarou a possibilidade de os tratados e convenções internacionais sobre direitos humanos receberam o status de emenda

28 Esse é o conceito apresentado pela Convenção sobre o Estatuto dos Apátridas em seu artigo 1. Segundo dados do Alto Comissariado das Nações Unidas para Refugiados (ACNUR), estima-se que, atualmente, existam 12 milhões de apátridas no mundo. ACNUR. Governo do Brasil anuncia projeto de lei para proteger pessoas sem pátria. Disponível em: <http://www.acnur.org/t3/ portugues/noticias/noticia/governo-do-brasil-anuncia-projeto-delei-para-proteger-pessoas-sem-patria/> . Acesso em: 30 ago. 2014.

29 Conceito que surgiu a partir do Caso Nottebohn, decidido pela Corte Internacional de Justiça.

30 A respeito, Marcelo Dias Varella destaca que os direitos humanos compõem um conjunto normativo forte, 'que se impõe aos Estados, não necessariamente por tratados, mas pelo avanço de discurso entre diferentes atores subnacionais', o que ocorre através da construção de uma 'lógica de pertencimento ou não a um grupo de países com padrões civilizatórios mais avançados', sendo que a 'desobediência ou não adoção de uma determinada proteção é considerada como um desvio do Estado em relação aos padrões de uma civilização mais avançada'. VARELLA, Marcelo Dias. As transformações do direito internacional e algumas visões sobre um eventual processo de constitucionalização. In LUCCA, Newton de; MEYER-PFLUG, Samantha Ribeiro; NEVES, Mariana Barboza Baeta (Coord.). Direito Constitucional Contemporâneo: Homenagem ao Professor Michel Temer. São Paulo: Quartier Latin do Brasil, 2012. p. 41.

Flávia Piovesan, por sua vez, destaca que a internacionalização dos direitos humanos gerou também a emergência de uma nova feição do Direito Constitucional ocidental, como se o Direito Internacional fosse transformado em parâmetro de validade das próprias Constituições nacionais, concepção inovadora que apresentou duas consequências principais: 1) a revisão da noção tradicional de soberania absoluta do Estado; 2) a cristalização da ideia de que o indivíduo deve ter direitos protegidos na esfera internacional, na condição de sujeito de direitos. PIOVESAN, Flávia. Direitos humanos e justiça internacional. 4. ed. rev., ampl. e atual. São Paulo: Saraiva, 2013. p. 43-44. constitucional caso aprovados segundo o mesmo procedimento delas. Quanto aos tratados ratificados anteriormente à mudança constitucional, o Supremo Tribunal Federal pacificou a matéria, atribuindo-lhes o caráter de supralegalidade e, portanto, incluindo-os na pirâmide normativa apenas abaixo da Constituição ${ }^{31}$.

Desse modo, pode-se concluir que os tratados ratificados pelo Brasil atinentes à redução dos casos de apatridia consistem em normas supralegais, considerado o caráter de direito humano conferido à nacionalidade, sendo de se adotar para nosso estudo, portanto, o viés do nacional como um sujeito de direitos em relação ao Estado, e não mero componente do elemento pessoal deste.

Ademais, a Corte Interamericana de Direitos Humanos, cuja competência o Brasil reconheceu, também já firmou posição de que devem os Estados ser proativos em matéria de nacionalidade, o que significa que eles não devem apenas se abster de produzir normas que tenham efeitos discriminatórios sobre o tema, mas também atuar na adoção de práticas ou legislações cuja aplicação favoreça a redução do número de pessoas apátridas em seu território ${ }^{32}$.

Apesar de todo esse arcabouço jurídico, é preciso observar se tais considerações estão sendo observadas por nosso direito interno nos casos de adoção internacional, sendo necessário, para tanto, primeiro analisar a evolução que também esse instituto sofreu.

\section{0 princípio da proteção ao interesse superior da criança e seus efeitos em matéria de nacionalidade nas hipóteses de adoção internacional}

O contexto pós-guerra, além de ter contribuído para o avanço da temática dos direitos humanos e para a incorporação, por esta, da questão atinente à nacionalidade, também constituiu o momento propício para o crescimento dos números de adoções

31 A decisão representou uma mudança na jurisprudência do STF a respeito da prisão do depositário infiel e foi adotada quando do julgamento dos Recursos Extraordinários RE 349703 e RE 466343 e do Habeas Corpus 87585. Por não ser o objetivo deste estudo, não iremos adentrar na divergência lançada por parte da doutrina em relação à decisão do STF quanto à ideia de supralegalidade dos tratados de direitos humanos e supraconstitucionalidade.

32 CORTE INTERAMERICANA DE DERECHOS HUMANOS. 2005. Sentença de 8 de septiembre, Niñas Yean $y$ Bosico v República Dominicana. Disponível em: <http://webcache. googleusercontent.com/search?q=cache:TDCsDySXg2sJ:www. corteidh.or.cr/docs/casos/articulos/seriec_130_esp. $\mathrm{doc}+\& \mathrm{~cd}=2 \& \mathrm{hl}=\mathrm{pt}-\mathrm{BR} \& \mathrm{ct}=\mathrm{clnk} \& \mathrm{gl}=\mathrm{br}>$. Acesso em: 10 set. 2014 . 
internacionais, pois se tratou de um período marcado pelo sacrifício de milhares de vidas e por um grande número de crianças órfãs.

Originalmente pensada como mecanismo para garantir a continuidade de famílias aristocráticas sem filhos, com a transmissão do nome e de seu patrimônio, a adoção internacional, no cenário das guerras mundiais, transmudou-se em mecanismo para garantir uma família a diversas crianças abandonadas, baseando-se precipuamente na ideia de afetividade.

Apesar desse histórico, apenas em 1993 houve a aprovação do primeiro instrumento a regular especificamente a matéria em caráter internacional ${ }^{33}$ : a Convenção da Haia relativa à Proteção das Crianças e à Cooperação em Matéria de Adoção Internacional, promulgada no Brasil pelo Decreto no 3.087, de 21 de junho de 1999, e que conclui pelo caráter excepcional e subsidiário da adoção internacional, admitindo-a somente depois de esgotadas todas as possibilidades de a criança viver de forma saudável em seu país de origem, no seio de sua família biológica ou mesmo em uma família adotiva nacional.

A excepcionalidade dessa forma de adoção se justificaria em virtude do Princípio da proteção ao interesse superior da criança, que tem por escopo priorizar a permanência do infante em seu país de origem, mantendo-lhe em contato com suas tradições, idioma e cultura, consoante estipulado pelo artigo 4 da Convenção, o qual condiciona o deferimento do pedido de adoção internacional ao esgotamento das possibilidades de colocação da criança em família de seu Estado de origem ${ }^{34}$.

33 Fala-se em "primeiro" por ter sido, realmente, o primeiro tratado a cuidar da matéria de modo universal e a contar com grande adesão, diferentemente de outros tratados sobre a matéria, que ou eram restritos a determinados Estados - como é o caso da Convenção Europeia em Matéria de Adoção, de 1967 - ou contaram com baixa adesão - como a Convenção Interamericana sobre Conflitos de Leis em Matéria de Adoção, de 1984.

34 BRASIL. Decreto n. 3.087, de 21 de junbo de 1999. Disponível em: $<$ http://www.planalto.gov.br/ccivil_03/decreto/d3087.htm>. Acesso em: 30 ago. 2014. Previsão no mesmo sentido é encontrada no Estatuto da Criança e do Adolescente em virtude das alterações promovidas em seu texto pela Lei $n^{\circ} 12.010$, de 2009 , a qual incluiu no art. 50 do ECA o $\$ 10$, segundo o qual A adoção internacional somente será deferida se, após consulta ao cadastro de pessoas ou casais habilitados à adoção, mantido pela Justiça da Infância e da Juventude na comarca, bem como aos cadastros estadual e nacional referidos no $\ 50$ deste artigo, não for encontrado interessado com residência permanente no Brasil. BRASIL. Lei n. 12.010, de 3 de agosto de 2009. Disponível em: <http://www. planalto.gov.br/ccivil 03/ ato2007-2010/2009/lei/112010. htm>. Acesso em: 04 set. 2014.
Uma vez preenchidos todos os requisitos estipulados pela Convenção, a adoção internacional poderá ser autorizada, hipótese em que, certificada sua ocorrência, deverá ser ela "reconhecida de pleno direito pelos demais Estados Contratantes" 35 , segundo redação do artigo 23.

A problemática residiria na ausência de uma definição sobre quais direitos deveriam ser plenamente reconhecidos, pelo Estado de acolhida, ao adotado, questão que ganha reforço no campo na nacionalidade, matéria que por sua própria natureza é autônoma, porquanto intimamente ligada ao regime constitucional nacional ${ }^{36}$.

$\mathrm{E}$ isso porque uma causa bastante frequente de apatridia consiste no choque entre os critérios de atribuição de nacionalidade, o que se reforça no campo da adoção internacional em virtude do rompimento que a criança sofre quanto ao seu vínculo biológico ${ }^{37}$, o qual, em alguns Estados, se estende ao próprio vínculo político, como ocorre, por exemplo, na Grécia e na Coreia, que preveem a adoção como hipótese de perda da nacionalidade ${ }^{38}$.

Embora diversas convenções busquem assegurar o direito à nacionalidade em prol das crianças, evitando que desde o nascimento elas estejam sem a proteção estatal $^{39}$, a única previsão específica sobre a matéria

35 BRASIL. Decreto n. 3.087, de 21 de junho de 1999. Disponível em: <http://www.planalto.gov.br/ccivil_03/decreto/d3087.htm>. Acesso em: 30 ago. 2014.

36 COSTA, Tarcísio José Martins. Adoção transnacional: um estudo sociojurídico e comparativo da legislação atual. Belo Horizonte: Del Rey, 1998. p. 157.

37 Isto porque, embora não contenha cláusula específica sobre o tema, pode-se entender que a Convenção da Haia relativa à Proteção das Crianças e à Cooperação em Matéria de Adoção Internacional preferiu adotar o sistema da confidencialidade em relação à origem da criança, pois, apesar de prever, em seu artigo 30, que serão conservadas as informações sobre sua origem e sobre seus pais biológicos, em outros dispositivos estabelece a total falta de contato entre os pais adotivos e os pais biológicos, impedindo que estes últimos tenham acesso a qualquer informação sobre os primeiros, devendo a adoção operar de pleno direito em relação ao Estado dos adotantes. GRANDINO, João Rodas; MONACO, Gustavo Ferraz de Campos(Org.). Conferência da Haia de Direito Internacional Privado: a participação do Brasil. Brasília: Fundação Alexandre de Gusmão, 2007. p. 316-317.

38 Esses exemplos são apresentados no Guia elaborado pela Conferência da Haia. HCCH. The implementation and operation of the 1993 Hague Intercountry Adoption Convention: Guide to good practice. 2008. Disponível em: <http://www.hcch.net/ index_en.php?act $=$ publications.details\&pid $=4388>$. Acesso em: 08 out. 2014.

39 Como é o caso da Convenção de 1961 para a redução dos 
nas hipóteses de adoção internacional constou da Convenção da Haia sobre Conflitos de Nacionalidade, de 1930, a qual previa em seu artigo 17 que

se a lei de um Estado admitir a perda da nacionalidade em consequência da adoção, esta perda ficará, entretanto, subordinada à aquisição pelo adotado da nacionalidade do adotante, de acordo com a lei do Estado, de que este for nacional, relativa aos efeitos da adoção sobre a nacionalidade ${ }^{40}$

Essa previsão, contudo, não foi reiterada na Convenção da Haia de 1993 relativa à proteção das crianças e à cooperação em matéria de adoção internacional, o que, considerando que a Convenção sobre Conflitos de Nacionalidade data de 1930, gerou um novo hiato em relação à nacionalidade dessas crianças, principalmente no Brasil, que, ao ratificar a Convenção da Haia sobre Conflitos de Nacionalidade, o fez com reserva em relação exatamente ao artigo 17 , considerando-se o regime constitucional da época ${ }^{41}$.

Este, contudo, não pode ser interpretado como um silêncio eloquente, considerando-se a ampla proteção que é conferida às crianças pelo direito das gentes, de modo que a interpretação do dispositivo constante da Convenção da Haia de 1993 deve estar pautada na equiparação plena de direitos entre todos os filhos, sejam eles naturais ou adotivos, uma vez que a adoção visa à completa integração do adotado no seio da nova família, o que não ocorrerá caso não se lhe conceda a nacionalidade do adotante ${ }^{42}$.

Nesse aspecto, vale destacar que o direito à equiparação entre os filhos já foi objeto de estudo pela Corte Europeia de Direitos Humanos no caso Marckx

casos de apatridia, já analisada, e também da Convenção sobre os Direitos da Criança, de 1989, promulgada no Brasil pelo Decreto ${ }^{\circ}$ 99.710, de 21 de novembro de 1990, a qual prevê em seu artigo 7 que a criança terá direito, desde o nascimento, a uma nacionalidade, cabendo aos Estados respeitar e garantir à criança a preservação de sua identidade, inclusive de sua nacionalidade. BRASIL. Decreto n. 99.710, de 21 de novembro de 1990. Disponível em: < http://www. planalto.gov.br/ccivil_03/decreto/1990-1994/D99710.htm>. Acesso em: 08 set. 2014.

40 MAZZUOLI, Valerio de Oliveira. Curso de direito internacional público. 2. ed. rev. atual. e ampl. São Paulo: Revista dos Tribunais, 2007. p. 571.

41 BRASIL. Decreto n. 21.798, de 6 de setembro de 1932. Disponível em: <http://legis.senado.gov.br/legislacao/ ListaTextoIntegral.action?id=34326. Acesso em: 4 set. 2014.

42 COSTA, Tarcísio José Martins. Adoção transnacional: um estudo sociojurídico e comparativo da legislação atual. Belo Horizonte: Del Rey, 1998 p. 157. versus Bélgica, julgado em 1979, e que teve por objeto o exame de uma lei belga que limitava os direitos sucessórios dos filhos de mãe solteira caso eles não fossem adotados pela própria mãe. Embora o caso não tratasse especificamente dos filhos adotivos, a posição adotada pela Corte na ocasião expôs o entendimento de que qualquer previsão legal que limite direitos apenas com base na origem da criança viola o direito de proteção à família, previsto sem quaisquer ressalvas pela Convenção Europeia de Direitos ${ }^{43}$.

Exatamente como decidiu a Corte Europeia, hoje, a adoção internacional é compreendida sob um outro viés, qual seja: o de mecanismo apto a garantir a todas as crianças o exercício de seu direito humano a uma família, a um lar que lhe propicie afeto, educação e uma vida digna, por ser este direito uma decorrência da própria noção de dignidade humana.

A impossibilidade de se discriminar uma criança em razão de sua origem ou em virtude de seus pais ou representantes legais é vedação contida de modo expresso, ainda, na Convenção das Nações Unidas sobre os Direitos da Criança, de 1989, que, em seu artigo 2, estipula que

os Estados Partes comprometem-se a respeitar e a garantir os direitos previstos na presente Convenção a todas as crianças que se encontrem sujeitas à sua jurisdição, sem discriminação alguma, independentemente de [...] sua origem nacional, étnica ou social, fortuna, incapacidade, nascimento ou de qualquer outra situação ${ }^{44}$.

Este tipo de vedação, baseada nos direitos humanos, justificou até mesmo que fosse delineada uma convenção europeia voltada a proteger as crianças nascidas fora do casamento ${ }^{45}$, demonstrando que, ainda que exista um silêncio normativo a respeito dos efeitos da equiparação entre filhos legítimos, ilegítimos e adotivos, este silêncio não pode ser interpretado como uma autorização à discriminação ${ }^{46}$.

43 EUROPEAN COURT OF HUMAN RIGHTS. Cours Européenne des Dois de L'Homme. 1979. Sentença de 13 de Junho. Marckx v. Bélgica. Application n. 6833/74. Disponível em: <http:// hudoc.echr.coe.int/sites/eng/pages/search.aspx?i=001-57534\# \{“it emid”:[“001-57534”]\}>. Acesso em: 7 set. 2014.

44 BRASIL. Decreto n. 99.710, de 21 de novembro de 1990. Disponível em: <http://www.planalto.gov.br/ccivil_03/decreto/1990-1994/ D99710.htm>. Acesso em: 08 set. 2014.

45 Infelizmente, essa Convenção, de 1975, foi objeto de baixa ratificação pelos Estados europeus.

46 Essa conclusão também foi apontada pela $\mathrm{CEDH}$ no caso 
Interpretar a adoção como um direito humano induz, inclusive, ao dever de garantir incentivos a esse meio de construção familiar, o que requer uma flexibilização das matérias consideradas de domínio exclusivo do Estado, como é o caso da nacionalidade ${ }^{47}$, pois, uma vez que o ato de adotar é voluntário - e assim deve continuar sendo - a obrigação por parte das instituições deve ser a de facilitar e fomentar a adoção, garantindo a esses jovens e crianças abandonados o direito a serem integrados em uma família no menor período de tempo possível ${ }^{48}$.

A influência dessa percepção levou a Conferência da Haia a editar a Recomendação no 17 , segundo a qual os Estados de acolhida devem buscar atribuir de modo automático, à criança adotada no contexto da Convenção da Haia, sua nacionalidade ou a nacionalidade de um dos adotantes da Haia. Quando isso não for possível de plano, devem adotar todas as medidas possíveis para facilitar a naturalização da criança, movidos sempre pelo objetivo de evitar que esses menores restem como apátridas ${ }^{49}$.

Marckx v. Bélgica. In EUROPEAN COURT OF HUMAN RIGHTS. Cours Européenne des Dois de L'Homme. 1979. Sentença de 13 de Junho. Marckx v. Bélgica. Application n. 6833/74. Disponível em: $<$ http://hudoc.echr.coe.int/sites/eng/pages/search.aspx?i=00157534\#\{“itemid”:[“001-57534”]\}>. Acesso em: 7 set. 2014.

47 Essa percepção, inclusive, é o que fundamenta a crítica de alguns autores à Convenção da Haia sobre Adoção Internacional de 1993, que não estaria "preocupada em como maximizar o cumprimento do direito humano daqueles privados da relação paisfilhos a serem adotados [...], ao contrário, demonstra desmedida obsessão com violações [...] do domínio monopolista dos Estados sobre suas populações." BARROZO, Paulo D. Por um lar no mundo: fundamentos jusfilosóficos do instituto da adoção como direito humano. Revista de Direito Administrativo, Rio de Janeiro, v. 262, p. 45-93, jan./abr. 2013. p. 53.

48 BARROZO, Paulo D. Por um lar no mundo: fundamentos jusfilosóficos do instituto da adoção como direito humano. Revista de Direito Administrativo, Rio de Janeiro, v. 262, p. 45-93, jan./abr. 2013. p. 83.

49 Tradução livre. O texto original da Recomendação dispõe: "The Special Commission recommends that the child be accorded automatically the nationality of one of the adoptive parents or of the receiving State, without the need to rely on any action of the adoptive parents. Where this is not possible, the receiving States are encouraged to provide the necessary assistance to ensure the child obtains such citizenship. The policy of Contracting States regarding the nationality of the child should be guided by the over riding importance of avoiding a situation in which an adopted child is stateless." HCCH. Conclusions and recommendations of the second meeting of the Special Commission on the practical operation of the Hague Convention of 29 May 1993 on Protection of Children and Co-operation in respect of Intercountry Adoption. Disponível em: <http://www.hcch. net/upload/wop/concl33sc05_e.pdf>. Acesso em: 10 out. 2014.
Em cumprimento a essa orientação, Inglaterra e Estados Unidos $^{50}$ alteraram suas legislações para garantir o reconhecimento automático de sua nacionalidade à criança adotada, bastando, para isso, que o país se torne o seu local de residência habitual. Outros Estados, como Itália ${ }^{51}$ e Suíça ${ }^{52}$, mantiveram a necessidade de um procedimento de homologação da sentença estrangeira de adoção, reconhecendo a atribuição da sua nacionalidade à criança, por sua vez, como um efeito automático não da Convenção da Haia, mas da decisão homologatória posterior.

Nesse cenário interpretativo, portanto, deve-se indagar qual é a posição do direito brasileiro sobre a matéria.

\section{Da postura do Brasil quanto ao reconhecimento da nacionalidade brasileira nos casos de adoção internacional}

No início deste estudo, destacamos a recente iniciativa legislativa do Poder Executivo na elaboração de normas internas voltadas à proteção dos migrantes e à redução do número de apátridas, o que rendeu o reconhecimento, pelo Alto Comissariado das Nações Unidas para Refugiados, de estar o Brasil ocupando papel de destaque na campanha global de redução dos casos de apatridia, situação que se soma ao fato de ser o país signatário da maioria das convenções internacionais que tratam do combate à apatridia, além da própria Convenção Americana de Direitos Humanos.

Contudo, o que se observa é que mesmo as medidas normativas mais recentes adotadas pelo país mantêm

50 Inglaterra, para tanto, editou o United Kingdom's Adoption Act 1999. UNITED KINGDOM. Adoption (Intercountry Aspects) Act 1999. Disponível em: <http://www.legislation.gov.uk/ ukpga/1999/18/contents>. Acesso em: 10 out. 2014. Os Estados Unidos, por sua vez, editaram o Child Citizenship Act 2000. UNITE STATE. Department of State. Acquiring U.S. Citizenship for your Child. Disponivel em: <http://travel.state.gov/content/adoptionsabroad/ en/us-visa-for-your-child/acquiring-us-citizenship-for-your-child. html>. Acesso em: 13 out. 2014.

51 A questão é regulada pela Lei italiana n. 184/83, com as alterações promovidas pela Lei n. 476/68. As informações a respeito são apresentadas em: MONTAGNER, Ângela Christina Boelhouwer. $A$ adoção internacional e a nacionalidade da criança adotada. Disponível em: <http://www.publicacoesacademicas.uniceub.br/ index.php/prisma/article/viewFile/903/849. Acesso em 13 de outubro de 2014>. Acesso em: 13 out. 2014

52 As informações estão disponíveis em: COSTA, Tarcísio José Martins. Adoção transnacional: um estudo sociojurídico e comparativo da legislação atual. Belo Horizonte: Del Rey, 1998. p. 347. 
o silêncio sobre a questão dos efeitos da adoção internacional no que se refere à nacionalidade, silêncio que encontra sua origem na Constituição de 1988, que prevê como brasileiros natos apenas as seguintes pessoas:

\author{
Art. 12. São brasileiros: \\ I- natos: \\ a) os nascidos na República Federativa do Brasil, \\ ainda que de pais estrangeiros, desde que estes não \\ estejam a serviço de seu país;
}

b) os nascidos no estrangeiro, de pai brasileiro ou mãe brasileira, desde que qualquer deles esteja a serviço da República Federativa do Brasil;

c) os nascidos no estrangeiro de pai brasileiro ou de mãe brasileira, desde que sejam registrados em repartição brasileira competente ou venham a residir na República Federativa do Brasil e optem, em qualquer tempo, depois de atingida a maioridade, pela nacionalidade brasileira; (Redação dada pela Emenda Constitucional $n^{\circ} 54$, de 2007)(grifo do autor) ${ }^{53}$

Ao falar especificamente em nascidos - expressão esta que foi mantida mesmo após as alterações realizadas no dispositivo pelas Emendas Constitucionais $\mathrm{n}^{\circ} 3$, de 1994 , e no 54 , de 2007, e que se encontra presente no anteprojeto de lei voltado a revogar o Estatuto do Estrangeiro - , a Constituição parece querer privilegiar o vínculo biológico como única fonte de atribuição de nacionalidade, o que, portanto, impediria que uma criança estrangeira adotada por pai brasileiro ou mãe brasileira, numa das hipóteses das alíneas "b" ou "c" do artigo 12, inciso I, pudesse ser considerada um brasileiro nato.

Contudo, a ideia atual de nacionalidade como direito humano e não mais mero fruto de reconhecimento estatal deve operar como critério para garantir uma atuação proativa do Estado não só na edição de normas, mas na interpretação daquelas já existentes, principalmente no que toca à primordial proteção que deve ser dada às crianças, evitando-se o crescimento do número de menores apátridas.

Este foi, inclusive, o norte interpretativo destacado pela Corte Interamericana de Direitos Humanos no

53 BRASIL. Constituição (1988). Constituição da República Federativa do Brasil. Disponível em: <http://www.planalto.gov.br/ ccivil_03/constituicao/constituicao.htm>. Acesso em: 01 set. 2014.
Parecer Consultivo OC-21/14, de 19 de agosto de 2014, elaborado em resposta à solicitação conjunta do Brasil, Argentina, Uruguai e Paraguai, com o fim de estabelecer quais as obrigações dos Estados com relação às medidas passíveis de serem adotadas a respeito de crianças migrantes.

No início de sua manifestação, a Corte destacou serem os tratados de direitos humanos instrumentos vivos, cuja interpretação deve acompanhar a evolução dos tempos e as condições de vida atuais, principalmente no que se relaciona à temática dos direitos das crianças, considerando que a Convenção sobre os Direitos da Criança constitui-se no tratado internacional com maior vocação de universalidade, não podendo, portanto, tal fato ser desconsiderado do contexto interpretativo ${ }^{54}$.

A essa ideia poderia ser somada, ainda, a previsão expressa da própria Constituição brasileira, que, em seu artigo $227, \$ 6^{\circ}$, estipula que

os filhos, havidos ou não da relação do casamento, ou por adoção, terão os mesmos direitos e qualificações, proibidas quaisquer designações discriminatórias relativas à filiação. ${ }^{55}$

Consistindo em vetor interpretativo expresso no texto constitucional.

Equiparados os filhos naturais e adotivos, e uma vez reconhecida de pleno direito a adoção internacional realizada, nos termos do que estipula a Convenção da Haia de 1993, a única consequência possível seria a ampliação das hipóteses de atribuição da nacionalidade brasileira também para os casos de crianças adotadas, inclusive para possibilitar a completa integração do menor ao país de acolhida, que será seu novo local de residência habitual.

Embora em uma análise superficial a questão pudesse parecer indene de maiores questionamentos, pois pareceria óbvia a necessidade de proteção do interesse da criança adotada, a demandar o reconhecimento da nacionalidade do país do adotante para permitir sua integral inclusão ao novo meio, não é isto que ocorre.

$\mathrm{Na}$ temática, o Brasil parece retroceder em sua postura mais avançada, adotando uma interpretação

54 CORTE INTERAMERICANA DE DERECHOS HUMANOS. Parecer Consultivo OC-21/14, de 19 de agosto de 2014. Disponível em: <http://www.corteidh.or.cr/docs/opiniones/ seriea_21_por.pdf $>$. Acesso em: 15 set. 2014.

55 BRASIL. Constituição (1988). Constituição da República Federativa do Brasil. Disponível em: <http://www.planalto.gov.br/ ccivil_03/constituicao/constituicao.htm>. Acesso em: 01 set. 2014 
restritiva quanto às hipóteses de aplicação do jus sanguinis como critério de atribuição de nacionalidade, no que é apoiado por farta doutrina, como destaca a obra abaixo citada:

[...] o Brasil anda na contramão de seu próprio entendimento, quando se trata de criança estrangeira adotada por brasileiro. [...]

O fundamento para tanto é que a impossibilidade de concessão de nacionalidade decorre do próprio texto constitucional que vincula o Brasil ao critério do jus soli ou, excepcionalmente, ao critério do jus sanguinis, no caso de filhos de brasileiros nascidos no exterior.

Esse entendimento é corroborado por Miguel Jerônymo Ferrante, o qual diz que 'filho adotivo de brasileiros, nascido no estrangeiro, não pode optar pela nacionalidade brasileira. É estrangeiro e, como tal, só poderá adquirir a nacionalidade brasileira por via de naturalização'. [...]

Também Francisco Guimarães afirma que 'a adoção de estrangeiro por brasileiro não produz efeitos sobre a nacionalidade'.

[...] Contudo, novamente entendendo-se que a adoção estabelece vínculo de filiação e que a própria Constituição Federal de 1988 proíbe qualquer designação discriminatória entre filhos, independentemente de sua origem, seja natural ou civil, não há por que dar tratamento diferenciado aos filhos adotados, sob pena de impor uma discriminação vedada pelo próprio texto constitucional no artigo 227, $\$ 6^{\circ}$ : [...] Se os filhos de brasileiros que nascem no exterior são brasileiros natos, os filhos adotados em outro país também deverão ser. ${ }^{56}$

Ocorre que a doutrina que comunga desse posicionamento adota uma posição simplista, baseada na literalidade da norma constitucional, como é o caso, por exemplo, de Valério Mazzuolli, que apoia essa posição unicamente sob o fundamento de o Brasil, no ato de sua ratificação à Convenção da Haia sobre Conflitos de Nacionalidade de 1930, ter feito reservas ao artigo 17 do texto, segundo o qual se

56 MONTAGNER, Ângela Christina Boelhouwer. A adoção internacional e a nacionalidade da criança adotada. Disponível em: $<$ http:// www.publicacoesacademicas.uniceub.br/index.php/prisma/article/ viewFile/903/849. Acesso em 13 de outubro de 2014>. Acesso em: 13 out. 2014 a lei de um Estado admitir a perda da nacionalidade em consequência da adoção, esta perda ficará, entretanto, subordinada à aquisição pelo adotado da nacionalidade do adotante, de acordo com a lei do Estado, de que este for nacional ${ }^{57}$.

Essa reserva, portanto, seria suficiente para garantir o entendimento de que a atuação brasileira deu-se em virtude do não reconhecimento expresso quanto à possibilidade de equiparação entre os filhos naturais e os adotivos.

De fato, embora tenha feito reservas ao mencionado dispositivo, é preciso considerar que o Decreto $\mathrm{n}^{\circ}$ 21.798, que promulgou a referida Convenção da Haia de 1930, foi publicado em 1932, quando ainda em vigor a Constituição de 1981, a qual explicitava concepção totalmente diversa sobre a temática, tendo sido a última Carta a prever, por exemplo, a distinção entre filhos legítimos e ilegítimos ${ }^{58}$.

A diferenciação constitucional, adequada à tradição em vigor no período de vigência da Carta de 1891, repercutia também nas normas infraconstitucionais, como é exemplo o Código Civil vigente à época, que concebia a adoção como um contrato e o parentesco dela decorrente como uma questão meramente de direito privado, incapaz de gerar quaisquer efeitos de direito público, mas apenas patrimoniais ${ }^{59}$.

Desse modo, não é possível que uma conclusão da época se mantenha ao longo dos anos, principalmente quando estamos diante da denominada 'Constituição cidadã de 1988', modelo para outros Estados em virtude dos vários direitos fundamentais reconhecidos em seu texto, e que deve ser, portanto, considerada um instrumento vivo de interpretação, nos termos propostos pela Corte Interamericana de Direitos Humanos.

$\mathrm{Na}$ prática, contudo, o que se constata é que essa postura restritiva e quase exegética quanto

57 MAZZUOLI, Valerio de Oliveira. Curso de direito internacional público. 2. ed. rev. atual. e ampl. São Paulo: Revista dos Tribunais, 2007 p. 571.

58 BRASIL. Constituição (1891). Constituição da República dos Estados Unidos do Brasil. Disponível em: < http://www.planalto.gov. br/ccivil_03/constituicao/constituicao91.htm>. Acesso em: 01 set. 2014. Acesso em: 7 set. 2014.

59 O cenário infraconstitucional da época é utilizado como argumento por Ilmar Penna Marinho para justificar a impossibilidade de a adoção gerar quaisquer efeitos relativos à nacionalidade em favor do adotado. MARINHO, Ilmar Penna. Adoção de nacionalidade no direito brasileiro. Revista Brasileira de Política Internacional, v.4, n. 16, p. 36-53, dez. 1961. 
à interpretação do dispositivo constitucional é encontrada também no Judiciário brasileiro, para quem a nacionalidade é expressão da soberania do Estado e sujeita a normas rígidas, sendo indiferente a vontade do indivíduo, como demonstra ementa de julgado proferido pelo Tribunal Regional Federal da $2^{\mathrm{a}}$ Região:

OPÇÃO DE NACIONALIDADE BRASILEIRA - NASCIDO NOS ESTADOS UNIDOS, FILHO ADOTIVO DE PAI NATURALIZADO BRASILEIRO E MÃE BRASILEIRA NATAART. 227, \ $6^{\circ}$, DA CRFB/88 - EQUIPARAÇÃO CIVIL - IMPROCEDÊNCIA.

1.A nacionalidade é expressão da soberania do Estado, sujeita a normas rígidas, não preponderando a vontade do indivíduo ou seus interesses.

$2 . \mathrm{O}$ art. 12, I, alínea "c" da CRFB/88 estabelece que são brasileiros natos, os nascidos de pai ou mãe brasileiros, em solo estrangeiro. Comprovou-se não ser o caso da Requerente, que se liga a pais brasileiros pelo vínculo da adoção.

$3 . \mathrm{O}$ art. $227, \int 6^{\circ}$, da $\mathrm{CRFB} / 88$, bem com a legislação infraconstitucional (o Código Civil e o Estatuto da Criança e do Adolescente), garantem tratamento sem discriminação aos filhos adotivos, equiparando-os aos biológicos, para fins civis e sucessórios. In casu, cuida-se de um direito público ligado à soberania do Estado, que a Carta Magna trata de forma particularmente restritiva.

4.A doutrina e a jurisprudência são unânimes ao reconhecer que o vínculo adotivo, no Brasil, não produz efeitos sobre a nacionalidade do adotante. A ser admitido tal posicionamento, estaríamos permitindo a fruição de direitos exclusivos de brasileiros natos, como o de jamais ser extraditado por eventuais crimes cometidos no exterior, ou de ocupar cargos como o de Presidente da República, violando cláusulas constitucionais extremamente rígidas.

5. Não se nega o direito à nacionalidade do Apelante, que lhe será conferida através do processo de naturalização.
6. Recurso desprovido. Sentença mantida ${ }^{60}$.

Embora essa posição não seja uniforme ao Judiciário brasileiro $^{61}$ nem possa ser tida por definitiva em virtude da ausência de uma posição do Supremo Tribunal Federal sobre o tema, ela conta com o respaldo do Ministério Público Federal, órgão responsável por defender os interesses dos incapazes e por velar pela regular aplicação da lei ${ }^{62}$, e se reforça quando observamos que prepondera uma posição patrimonialista sobre os efeitos da adoção ${ }^{63}$, entendendo-se que a previsão

60 BRASIL. Tribunal Regional Federal do Rio de Janeiro (2. Região). Apelação Cível n. 436220. Processo n. 200850010027446/ RJ. Órgão Julgador: Sexta Turma Especializada. Relator: Desembargador Federal Frederico Gueiros. Data da decisão: 20/09/10. Disponível em: <http://jurisprudencia.trf2.jus.br/v1/ search?q=cache:JHceX42kwEwJ:www.trf2.com.br/idx/trf2/ement as $/ \% 3$ Fprocesso $\% 3$ D200850010027446\%26CodDoc $\% 3 D 240160$ + nacionalidade + brasileira + ado $\% \mathrm{C} 3 \% \mathrm{~A} 7 \% \mathrm{C} 3 \% \mathrm{~A} 3 \mathrm{o}+$ internaciona $1+\&$ client $=$ jurisprudencia\&output $=x$ ml_no_dtd\&proxystylesheet $=$ jurisprudencia\&lr $=$ lang_pt\&ie $=U$ UTF-8\&site $=$ ementas\&access $=p \&$ oe $=U$ TTF-8 $>$. Acesso em: 01 set. 2014.

Também no TRF $2^{a}$ Região é possível localizar, no mesmo sentido, o seguinte acórdão: Apelação Cível no 401112. Processo $\mathrm{n}^{\circ}$ 200651020040465/RJ RIO DE JANEIRO. Tribunal Regional Federal (2. Região). Apelação Cível n.401112. Processo n. 2006510200404651. Órgão Julgador: Sexta Turma Especializada. Relator: Desembargador Federal Frederico Gueiros. Data da decisão: 25/02/08. Disponível em: <http://jurisprudencia.trf2. jus.br/v1/search?q=cache:c5FvQ3GMhJoJ:www.trf2.com. $\mathrm{br} / \mathrm{idx} / \mathrm{trf2} / \mathrm{ementas} / \% 3$ Fprocesso\%3D200651020040465 $\% 26$ CodDoc $\% 3 D 178728+200651020040465+\&$ client $=$ ju risprudencia\&output $=\mathrm{xml}$ no $\mathrm{dtd} \&$ proxystylesheet $=\mathrm{juris}$ prudencia\&lr=lang_pt\&ie $=\mathrm{UTF}-8 \&$ site $=$ ementas\&access $=$ p\&oe $=$ UTF-8 $>$. Acesso em: 01 set. 2014.

Posição semelhante é também localizada no TRF $3^{\text {a }}$ Região: SÃO PAULO. Tribunal Regional Federal (3. Região). Apelação Cível n. 759974. Processo n 00152309620004036100. Órgão Julgador: Terceira Turma. Relator: Desembargador Federal Baptista Pereira. DJU: 11/09/2002. Disponível em: < http://web. trf3.jus.br/consultas/Internet/ConsultaProcessual/Processo?Num eroProcesso $=00152309620004036100>$. Acesso em: 28 out. 2014 .

61 Em sentido contrário, é possível localizar o Processo $n$. 48595-64.2011.4.01.3400, ajuizado perante a Justiça Federal no Distrito Federal, cujo pedido foi julgado procedente.

62 Mesmo no precedente favorável encontrado, o Ministério Público Federal proferiu parecer pela improcedência do pedido, arguindo, justamente, a literalidade do art. 12 da Constituição, posição esta que foi defendida e acolhida nos outros três casos citados, julgados pelos TRFs da $2^{\mathrm{a}}$ e $3^{\mathrm{a}}$ Regiões.

63 No julgamento da Ação Rescisória n 1811/PB, o STF definiu que a previsão do art. $227, \$ 6^{\circ}$, da Constituição não autorizaria a não aplicação do artigo 377 do Código Civil de 1916, que previa que a sucessão ocorreria apenas em favor dos filhos naturais, não atingindo os adotivos.

A conclusão do julgamento foi noticiada no informativo $n^{\circ}$ 741, não tendo sido ainda disponibilizado o inteiro teor do acórdão. BRASIL. Supremo Tribunal Federal. Informativo n. 741, Brasília, 31 de março a 4 de abril de 2014. Disponível em: < http://www.stf.jus. 
do artigo 227, $₫ 6^{\circ}$, da Constituição, ao estipular a equiparação de direitos entre os filhos naturais e os adotivos, apenas opera seus efeitos para o futuro e para fins civis e sucessórios, não se aplicando a hipóteses anteriores a 1988, ainda que simplesmente corresponda a um corolário do princípio da igualdade.

Contudo, como destacamos, mesmo no aspecto civil e sucessório, as Cortes Regionais de Direitos Humanos vêm garantindo a plena equiparação entre os filhos, pautando-se, para tanto, no direito humano à proteção da família, que não é estipulado com quaisquer ressalvas, tampouco apenas de modo ex nunc ${ }^{64}$. Assim, embora possa o legislador prever limites à sucessão, tais limitações não podem estar pautadas em questões discriminatórias, como é o caso daquelas existentes entre os filhos naturais e os adotivos unicamente com base no nascimento.

Desse modo, é possível verificar que, tanto no âmbito doutrinário quanto no âmbito judicial, a posição adotada pelo direito brasileiro é uma posição restritiva, que interpreta de modo eloquente o silêncio constitucional para considerá-lo como uma vedação à possibilidade de inclusão dos filhos adotivos dentre os brasileiros natos nas hipóteses em que adotado o critério do jus sanguinis.

Apenas na prática administrativa foi possível verificar a aplicação, pelo Poder Executivo, de entendimento favorável à extensão da condição de brasileiro nato ao filho adotivo por meio da aplicação conjunta dos artigos 12, inciso I, alínea "c" e 227, $\$ 6^{\circ}$, da Constituição, garantindo à criança adotada o reconhecimento da sua condição de brasileiro nato por meio do registro em repartição consular.

Exemplo dessa posição foi manifestada por meio do Parecer no 025/2013/CEP/CONJUR-MJ/CGU/ $\mathrm{AGU}^{65}$, expedido pela Consultoria Jurídica junto ao

$\mathrm{br} / /$ arquivo/informativo/documento/informativo741.htm\#AR: filho adotivo e direito de suceder antes da CF/1988 - 3>. Acesso em: 01 set. de 2014

64 No já citado caso Marckx v. Bélgica, a CEDH enfatizou que a vida familiar, protegida pela Convenção Europeia de Direitos Humanos, deve envolver não apenas questões sociais, culturais ou morais, mas ir além, para garantir a proteção dos meios materiais necessários para o seu desenvolvimento, o que inclui, também, a proteção integral a questões sucessórias, das quais não podem ser excluídos os filhos com base em sua origem. In EUROPEAN COURT OF HUMAN RIGHTS. Cours Européenne des Dois de L'Homme. 1979. Sentença de 13 de Junho. Marckx v. Bélgica. Application n. 6833/74. Disponível em: <http://hudoc.echr. coe.int/sites/eng/pages/search.aspx?i=001-57534\# \{“item id”:[“001-57534”] \} >. Acesso em: 7 set. 2014.

65 Este parecer foi obtido junto ao Ministério da Justiça através
Ministério da Justiça em resposta à consulta formulada pelo Ministério das Relações Exteriores sobre a possibilidade de registro consular de menor estrangeiro adotado por brasileiros no exterior. E, embora o caso não tratasse especificamente de uma adoção internacional - já que adotante e adotado possuíam o mesmo local de residência habitual, mas nacionalidades distintas —, a fundamentação apresentada na análise do pedido demonstra a possibilidade de utilização do mesmo entendimento para os casos regidos pela Convenção da Haia de 1993, já que observa o silêncio constitucional e o interpreta favoravelmente à aplicação do artigo 227, $\$ 6^{\circ}$ da Constituição, concluindo que

[...] o menor estrangeiro adotado por brasileiros no exterior terá direitos iguais aos de um filho biológico, sem quaisquer diferenciações, conforme preceitua a nossa Constituição Federal, o que lhe garante, portanto, o registro consular de nascimento pela autoridade consular, após o término do processo de adoção no país local e a homologação da sentença perante o Superior Tribunal de Justiça, ficando garantida ao mesmo a aplicação do teor da alínea "c" do artigo 12 de nossa Carta constitucional.

Apesar de, na prática, o Poder Executivo estar adotando, em situações individuais, medidas consonantes a uma interpretação sistemática do texto constitucional, não é possível distinguir a posição de cada um dos Poderes do Estado e analisá-las em separado perante o Direito internacional. O Estado, para o direito das gentes, é um só, de modo que, ao se tornar parte de um tratado, este obriga todos os seus órgãos, e a violação por parte de um desses órgãos deve implicar a responsabilidade do Estado como um todo.

Com isso, é possível concluir que, quanto ao Estado brasileiro, prevalece uma posição restritiva a respeito da nacionalidade nas hipóteses de adoção internacional, a qual estaria em desconformidade à posição de vanguarda que o Brasil vem adotando no que se refere ao combate à apatria, e - pode-se dizer — em contrariedade à Opinião Consultiva recentemente proferida pela Corte Interamericana a pedido do país.

de pedido formulado pelo Sistema de Acesso à Informação e consta como Anexo a este artigo. Vale destacar que, embora ele expresse posição da Consultoria Jurídica junto ao Ministério da Justiça, não o faz de modovinculante, pois não se trata de Parecer aprovado pelo Presidente da República. Sua menção neste artigo dá-se com o fim de demonstrar a posição mais avançada do Poder Executivo sobre a matéria. 


\section{Conclusão}

Por força da característica de instrumentos vivos de transformação social, os tratados relativos a direitos humanos devem ser interpretados com base na ideia de efetividade, do que resulta, para os Estados, tanto o dever de suprimir normas e práticas internas que representem violações aos direitos naqueles consagrados, quanto o de atuar de modo proativo na adoção de medidas conducentes à observância das garantias naqueles previstas.

Quanto ao Brasil, foi possível observar ser o país signatário de vários tratados relativos a direitos humanos e direcionados ao combate à apatria, sendo que a própria Constituição Brasileira de 1988 já representava um importante avanço na temática, por consagrar em seu texto uma infinidade de direitos e garantias fundamentais à pessoa humana.

Considerando-se, contudo, a impossibilidade de previsão escrita de todas as possibilidades de choque entre princípios e fundamentos do Estado com suas respectivas soluções, a Constituição de 1988 acabou sendo silente a respeito dos efeitos diretos da adoção internacional no que se refere à nacionalidade da criança adotada.

Esse silêncio não poderia ser interpretado como proposital ou como vedação à ampliação das hipóteses de aplicação do critério do jus sanguinis, principalmente em virtude do quanto disposto no artigo $227, \$ 6^{\circ}$, da Constituição, que prevê a equiparação de direitos entre os filhos naturais e adotivos, sem qualquer ressalva quanto aos direitos que deveriam ser estendidos, se limitados a direitos patrimoniais ou não, justo por ter por fundamento a proteção à família, cuja composição não pode ser objeto de exceções.

Apesar disso, e apesar de todas as medidas legislativas que o país vem adotando na temática do combate à apatria, foi possível perceber que, na interpretação de suas normas, prevalece, em nosso direito interno, uma postura conservadora a respeito da nacionalidade, que a considera fruto do reconhecimento estatal mais do que um direito humano, visão esta, contudo, que não mais encontra respaldo no cenário internacional.

Desse modo, torna-se possível concluir que mais importante do que a edição de novas normas sobre a matéria é a correta interpretação dos dispositivos já vigentes, adotando-se por linha interpretativa o princípio de que a Constituição não possui termos inúteis, devendo ser compreendida a partir de sua teleologia e de seu contexto geral, como instrumento vivo de proteção a direitos humanos, não se podendo retroceder a uma posição exegética e conservadora.

Assim, atribuir a nacionalidade brasileira à criança adotada por pai ou mãe brasileiro nas hipóteses listadas no artigo 12, inciso I, alíneas "b" e "c", da Constituição de 1988, não significa ir além dos limites fixados pelo Constituinte, mas compreender que não há, no caso, um verdadeiro silêncio, mas a necessidade de observação do texto constitucional como um todo harmônico, que nos leva a transportar o dever de equiparação entre os filhos também para as hipóteses de reconhecimento da nacionalidade brasileira, mesmo nas hipóteses de aplicação do critério excepcional do jus sanguinis. 


\section{Referências}

ARENDT, Hannah. As origens do totalitarismo. Tradução Roberto Raposo. São Paulo: Companhia das Letras, 1989.

BARROZO, Paulo D. Por um lar no mundo: fundamentos jusfilosóficos do instituto da adoção como direito humano. Revista de Direito Administrativo, Rio de Janeiro, v. 262, p. 45-93, jan./abr. 2013.

BRASIL. Constituição (1891). Constituição da República dos Estados Unidos do Brasil. Disponível em: <http://www. planalto.gov.br/ccivil_03/constituicao/constituicao91. htm>. Acesso em: 01 set. 2014. Acesso em:7 set. 2014.

BRASIL. Constituição (1988). Constituição da República Federativa do Brasil. Disponível em: <http://www. planalto.gov.br/ccivil_03/constituicao/constituicao. htm>. Acesso em: 01 set. 2014.

BRASIL. Decreto n. 2.411, de 23 de fevereiro de 1938. Disponível em: <http://www2.camara.leg.br/legin/fed/ decret/1930-1939/decreto-2411-23-fevereiro-1938-345944publicacaooriginal-1-pe.html>. Acesso em: 30 ago. 2014.

BRASIL. Decreto n. 21.798, de 6 de setembro de 1932. Disponível em: <http://legis.senado.gov.br/legislacao/ ListaTextoIntegral.action?id=34326. Acesso em: 4 set. 2014 .

BRASIL. Decreto n. 3.087, de 21 de junho de 1999. Disponível em: <http://www.planalto.gov.br/ccivil_03/decreto/ d3087.htm>. Acesso em: 30 ago. 2014.

BRASIL. Decreto n. 4.246, de 22 de maio de 2002. Disponível em: <http://www.planalto.gov.br/ccivil_03/decreto/2002/ D4246.htm>. Acesso em: 30 ago. 2014.

BRASIL. Decreto n. 99.710, de 21 de novembro de 1990. Disponível em: <http://www.planalto.gov.br/ccivil_03/ decreto/1990-1994/D99710.htm>. Acesso em: 08 set. 2014..

BRASIL. Decreto $n^{\circ} 678$, de 6 de novembro de 1992. Disponível em: <http://www.planalto.gov.br/ccivil_03/decreto/ D0678.htm>. Acesso em: 30 ago. 2014.

BRASIL. Lei n. 12.010, de 3 de agosto de 2009. Disponível em: <http://www.planalto.gov.br/ ccivil_03/_ato2007-2010/2009/lei/112010.htm>. Acesso em: 04 set. 2014.
BRASIL. Supremo Tribunal Federal. Ação Rescisória $n^{o}$ 1811/PB. Disponível em: <http://www.stf.jus.br// arquivo/informativo/documento/informativo741. htm\#AR: filho adotivo e direito de suceder antes da CF/1988 - 3>. Acesso em: 01 set. 2014.

BRASIL. Tribunal Regional Federal de São Paulo. (3. Região). Apelação Cível n. 759974. Processo $n$ 00152309620004036100. Órgão Julgador: Terceira Turma. Relator: Desembargador Federal Baptista Pereira. DJU: 11/09/2002. Disponível em: <http://web. trf3.jus.br/consultas/Internet/ConsultaProcessual/Pr ocesso? NumeroProcesso $=00152309620004036100>$. Acesso em: 28 out. 2014.

BRASIL. Tribunal Regional Federal do Rio de Janeiro. (2. Região). Apelação Cível n. 436220. Processon. 200850010027446/RJ. Órgão Julgador: Sexta Turma Especializada. Relator: Desembargador Federal Frederico Gueiros. Data da decisão: 20/09/10. Disponível em: <http://jurisprudencia.trf2.jus.br/v1/ search?q=cache:JHceX42kwEwJ:www.trf2.com.br/ $\mathrm{idx} / \mathrm{trf2} /$ ementas/\%3Fprocesso\%3D20085001002744 $6 \% 26 \mathrm{CodDoc} \% 3 \mathrm{D} 240160+$ nacionalidade+brasileira+ $\mathrm{ado} \% \mathrm{C} 3 \% \mathrm{~A} 7 \% \mathrm{C} 3 \% \mathrm{~A} 3 \mathrm{o}+$ internacional $+\& \mathrm{client}=$ juris prudencia\&output $=x m l \_n o \_d t d \&$ proxystylesheet $=$ jur isprudencia\&lr=lang_pt\&ie $=U T$ TF-8\&site $=$ ementas \&a ccess $=$ p\&oe $=U T F-8>$. Acesso em 01 set. 2014.

BRASIL. Tribunal Regional Federal do Rio de Janeiro. (2. Região). Apelação Cível n.401112. Processo n. 2006510200404651. Órgão Julgador: Sexta Turma Especializada. Relator: Desembargador Federal Frederico Gueiros. Data da decisão: 25/02/08. Disponível em: <http://jurisprudencia.trf2.jus.br/v1/ search?q= cache:c5FvQ3GMhJoJ:www.trf2.com.br/idx/ trf2/ementas/\%3Fprocesso\%3D200651020040465\%26 CodDoc\%3D178728+200651020040465+\&client=juris prudencia\&output=xml_no_dtd\&proxystylesheet $=$ juris prudencia\&lr $=$ lang_pt\&ie $=$ UTF-8\&site $=$ ementas $\&$ acc ess $=$ p\&oe $=U T F-8>$. Acesso em: 01 set. 2014..

BUSTAMANTE, Thomas da Rosa. Teoria do precedente judicial: a justificação e a aplicação das regras jurisprudenciais. São Paulo: Noeses, 2012.

CORTE INTERAMERICANA DE DERECHOS HUMANOS. 2005. Sentença de 8 de septiembre, Niñas Yean y Bosico v República Dominicana. Disponível em: $\quad<$ http://webcache.googleusercontent.com/ search?q=cache:TDCsDySXg2sJ:www.corteidh. 
or.cr/docs/casos/articulos/seriec_130_esp. $\mathrm{doc}+\& \mathrm{~cd}=2 \& \mathrm{hl}=\mathrm{pt}-\mathrm{BR} \& \mathrm{ct}=\mathrm{clnk} \& \mathrm{gl}=\mathrm{br}>$. Acesso em: 10 set. 2014.

CORTE INTERAMERICANA DE DERECHOS HUMANOS. Parecer Consultivo OC-21/14, de 19 de agosto de 2014. Disponível em: <http://www.corteidh.or.cr/ docs/opiniones/seriea_21_por.pdf $>$. Acesso em: 15 set. 2014.

CORTE INTERAMERICANA DE DERECHOS. 2001. Sentença de 6 de fevereiro, Ivcher Bronstein v. Peru. Disponível em: <http://www.corteidh.or.cr/docs/ casos/articulos/Seriec_74_esp.pdf. Acesso em: 10 set. 2014.

COSTA, Tarcísio José Martins. Adoção transnacional: um estudo sociojurídico e comparativo da legislação atual. Belo Horizonte: Del Rey, 1998.

EUROPEAN COURT OF HUMAN RIGHTS. Cours Européenne des Dois de L'Homme. 2011. Sentença de 11 de outubro, Genovese v. Malta, Application no. 53124/09. Disponível em: <http://hudoc.echr.coe. int/sites/eng/pages/search.aspx?i=001-106785\#\{“item id”:[“001-106785”] \}>. Acesso em: 30 ago. 2014.

EUROPEAN COURT OF HUMAN RIGHTS. Cours Européenne des Dois de L'Homme. 1979. Sentença de 13 de Junho. Marckx v. Bélgica. Application n. 6833/74. Disponível em: <http://hudoc.echr.coe. int/sites/eng/pages/search.aspx?i=001-57534\#\{“item id”:[“001-57534”]\}>. Acesso em: 7 set. 2014.

FONTES, André R. C. Nacionalidade brasileira e adoção internacional. Disponível em: <www.tre-ri.gov.br/eje/gecoi_ arquivos/arq_051202.docx>. Acesso em: 30 ago. 2014.

GRANDINO, João Rodas; MONACO, Gustavo Ferraz de Campos(Org.). Conferencia da Haia de Direito Internacional Privado: a participação do Brasil. Brasília: Fundação Alexandre de Gusmão, 2007

$\mathrm{HCCH}$. Conclusions and recommendations of the second meeting of the Special Commission on the practical operation of the Hague Conventionof 29 May 1993 on Protection of Children and Cooperation in respect of Intercountry Adoption. Disponível em: <http://www.hcch.net/upload/wop/concl33sc05_e. pdf $>$. Acesso em: 10 out. 2014.
$\mathrm{HCCH}$. The implementation and operation of the 1993 Hague Intercountry Adoption Convention: Guide to good practice. 2008. Disponível em: <http:// www.hcch.net/index_en.php?act=publications. details\&pid $=4388>$. Acesso em: 08 out. 2014.

HERANI, Renato Gugliano. Nacionalidade potestativa após a Emenda Constitucional 54/07. Disponível em: $<$ http://www.periodicos.ufgd.edu.br/index.php/ videre/article/viewFile/899/pdf_49. Acesso em: 8 nov. 2012.

LOPES, Cristiane Maria Sbalqueiro. Direito de imigração: o Estatuto do Estrangeiro em uma perspectiva de Direitos Humanos. Porto Alegre: Núria Fabris, 2009.

MARINHO, Ilmar Penna. Adoção de nacionalidade no direito brasileiro. Revista Brasileira de Política Internacional, v.4, n. 16, p. 36-53, dez. 1961.

MAZZUOLI, Valerio de Oliveira. Curso de direito internacional público. 2. ed. rev. atual. e ampl. São Paulo: Revista dos Tribunais, 2007.

MONTAGNER, Ângela Christina Boelhouwer. Aadoção internacional e a nacionalidade da criança adotada. Disponível em: <http://www.publicacoesacademicas.uniceub.br/ index.php/prisma/article/viewFile/903/849. Acesso em 13 de outubro de 2014>. Acesso em: 13 out. 2014.

ORGANIZAÇÃO DAS NAÇÕES UNIDAS. Convenção para a redução dos casos de apatridia. Disponível em: $<$ http://www.acnur.org/t3/fileadmin/Documentos/ portugues/BDL/Convencao_para_a_Reducao_dos_ Casos_de_Apatridia_de_1961.pdf?view=1>. Acesso em: 30 ago. 2014.

ORGANIZAÇÃO DAS NAÇÕES UNIDAS. Declaração Universal dos Direitos do Homem de 1948. Disponível em: <http://www.ohchr.org/EN/UDHR/ Documents/UDHR_Translations/por.pdf $>$. Acesso em: 30 ago. 2014.

PIOVESAN, Flávia. Direitos humanos ejustiça internacional. 4. ed. rev., ampl. e atual. São Paulo: Saraiva, 2013..

REZEK, Francisco. Direito internacional público: curso elementar. 14. ed., rev., aumen. e atual. São Paulo: Saraiva, 2013. 
REZEK, José Francisco. Le Droit International de la Nationalité. Leiden: M. Nijhoff, 1987. (Recueil des Cours de l'Académie de droit international, 198).

VARELLA, Marcelo Dias. As transformações do direito internacional e algumas visões sobre um eventual processo de constitucionalização. In LUCCA, Newton de; MEYER-PFLUG, Samantha Ribeiro; NEVES, Mariana Barboza Baeta (Coord.). Direito Constitucional Contemporâneo: homenagem ao Professor Michel Temer. São Paulo: Quartier Latin do Brasil, 2012.

VARELLA, Marcelo Dias. Direito internacional público. 3. ed. São Paulo: Saraiva, 2011. 
Para publicar na Revista de Direito Internacional, acesse o endereço eletrônico www.rdi.uniceub.br ou www.brazilianjournal.org.

Observe as normas de publicação, para facilitar e agilizar o trabalho de edição. 